\title{
The role of integrating agroforestry and vegetable planting in structuring communities of herbivorous insects and their natural enemies in the Neotropical region
}

\author{
Érica Sevilha Harterreiten-Souza • \\ Pedro Henrique Brum Togni · Carmen \\ Silvia Soares Pires $\cdot$ Edison Ryoiti Sujii
}

Received: 17 May 2013/Accepted: 14 December 2013/Published online: 5 January 2014

(C) Springer Science+Business Media Dordrecht 2014

\begin{abstract}
The integration of agroforestry plots with ephemeral crops such as vegetables on the farm scale can probably serve as a refuge and source of beneficial insects. Therefore, agroforestry systems possibly represent an alternative that favors ecosystem services and help growers in the transition process from conventional to agro-ecological agriculture. This study aimed to understand the role of introducing agroforestry systems in structuring insect communities, with consequences for the abundance of herbivore and natural enemies, contributing to farm management and favoring biological control as an ecosystem service. Field surveys showed that agroforestry
\end{abstract}

\section{É. S. Harterreiten-Souza}

PPG Ecologia, Instituto de Ciências Biológicas, Universidade de Brasília, Campus Darcy Ribeiro, Brasília, Distrito Federal 70910-900, Brazil

e-mail: ericsevilha@hotmail.com

\section{É. S. Harterreiten-Souza · P. H. B. Togni}

Departamento de Entomologia, Universidade Federal de Viçosa, Av PH Holfs s/n, Campus Universitário, Viçosa, Minas Gerais 36570-000, Brazil

e-mail: phbtogni@gmail.com

P. H. B. Togni · C. S. S. Pires · E. R. Sujii ( $\square)$

Empresa Brasileira de Pesquisa Agropecuária,

EMBRAPA Recursos Genéticos e Biotecnologia, Parque

Estação Biológica, Asa Norte, Brasília,

Distrito Federal 70770-917, Brazil

e-mail: edison.sujii@embrapa.br

C. S. S. Pires

e-mail: carmen.pires@embrapa.br systems can harbor more species than horticultural crops, independent of the functional group. They also contain a greater diversity of herbivores and an even greater diversity profile of natural enemy communities. Agroforestry systems served as a source of natural enemies that can colonize horticultural crops when herbivores are present. As a consequence, natural enemies can establish a numerical response to herbivore abundance, but their communities are also affected by stochastic factors related to climatic conditions. Thus, agroforestry systems and agroecological practices might favor an agriculture based on the maintenance and conservation of ecosystem services.

Keywords Agroecology · Biological control · Ecological pest management $\cdot$ Ecosystems services $\cdot$ Functional groups

\section{Introduction}

The targets of biodiversity conservation and food production have taken a new perspective since the Millennium Ecosystem Assessment in 2005 (Perrings et al. 2010, 2011, Ferreira et al. 2012; Melo et al. 2013). It was proposed that the efforts of conservation should focus on the services that biodiversity can provide, instead of only on the conservation of taxonomic diversity per se (Perrings et al. 2010, 2011). These ecosystem services are provided not only 
in natural landscapes such as agricultural ones, but also in human-dominated landscapes such as urban centers (Melo et al. 2013). Moreover, landscapes worldwide are a mixture of natural and agricultural areas. For example, Brazil is considered a megadiverse country as well as being one of the main producers of food and fiber of the world (Ferreira et al. 2012). Thus, it provides an opportunity to integrate the needs of food production with nature conservation, by changing farm design based on an agro-ecological concept. Originally, the agro-ecological concept is defined as the application of ecological principles to agriculture, in order to use ecosystems services provided by the biodiversity conservation instead of artificial external outputs in farm management. (Altieri et al. 1983; Gliessman 2007). The first step to accomplish this is to identify the needs of the people involved and select plants that will compose the agrosystem's diversity in a functional way (Altieri 1999; Lin et al. 2011; Perrings et al. 2011).

A major problem in agro-ecological systems is herbivore insect outbreaks that can cause production loss because growers are not permitted to spray chemical insecticides (Ratnadass et al. 2011). The problem with insect pest outbreaks is more evident when a conventional grower is moving towards an agro-ecological system. During this "transition" phase, several changes in the insect communities can occur until it reaches an acceptable level of dynamic equilibrium with a well-established pool of species in the area (Altieri and Nicholls 2009). Due to this, growers need to manage the farm to favor the ecosystem services, such as nutrient and water cycling, herbivory, pollination and, specially, biological control of pest and disease (de Groot et al. 2002). This latter ecosystem service will depend mainly on understanding the dynamics of herbivores and their natural enemies on the farm scale and how specific traits of each functional group can be favored (Andow 1991; Scherber et al. 2010; Vandewalle et al. 2010).

There are several agricultural management practices that can be used to favor biological control conservation, such as enhancing diversity of crops (poly-cultures and intercropping) instead of monoculture crops, planting different varieties of the same crop, management of non-crop vegetation (e.g. weeds) inside the crop plots (Gurr et al. 2003; Sujii et al. 2010). Nevertheless, the magnitude of these effects varies according to the strategy used (Letourneau et al.
2011). Thus, increasing plant diversity within the plot is considered one of the main techniques to favor biological control (Ratnadass et al. 2011; ChaplinKramer and Kremen 2012). In some ephemeral crops such as vegetables, the efficiency of these strategies can be conditioned to the pool of species available in the area (Tylianakis et al. 2005). Therefore, it is necessary to understand the functional group interactions at the plot level. Interactions with habitats in the landscape and abiotic conditions also play an important role in biological control efficiency and in understanding why the enhancement of vegetation diversity can affect this service (Tscharntke et al. 2007).

The establishment of agroforestry systems is one of the strategies that can be considered important to integrate conservation and food production needs and also favor biological control (Pastur et al. 2012). These agroforestry systems are characterized by a mixture of different species of plants that can be native or introduced, used for multiple purposes including crop production, fruit harvesting, timber extraction, native species conservation outside of reserves and also human well-being (Tscharntke et al. 2011). In tropical region, agroforestry systems also serve as a refuge for many species of animals. According to Bhagwat et al. (2008), for some animal taxa such as insects, there is a great similarity in species between natural areas and agroforestry systems. Therefore, increasing the diversity of plants in the agricultural landscape, by the introduction of an agroforestry system plots among ephemeral plots of vegetables, can provide alternative resources such as pollen and nectar, herbivore preys and other favorable conditions to natural enemies, and serve as source of these beneficial insects in the farm Thus, it is possible that agroforestry systems represent an alternative to favor ecosystem services and help growers in the transition process from conventional agriculture to agro-ecological systems.

To test these assumptions, in 2008, some small growers from the Federal District in Brazil engaged in the agro-ecological transition from conventional to an ecological-based model of vegetable production. To accomplish this, a research institution together with a federal university and a local extension agency worked with these growers to change farm design in a participatory way. Strips of agroforestry systems were planted as the first step of this process on all farms. This study was conducted in areas located in the Cerrado biome, the Brazilian tropical savanna. The 
Cerrado is the second major vegetation type in Brazil, occupying about one quarter of the Brazilian land area. As well as its importance as the second major vegetation type in Brazil and a hotspot of biodiversity (Myers et al. 2000), the Cerrado is also considered the main agricultural frontier in the country (Sparovek et al. 2010). Consequently, the Cerrado presents a highly fragmented landscape that is permeated by extensive monocultures of soybean, cotton, corn and pastures (Sparovek et al. 2010). However, in Brazil, the food produced for internal consumption is produced mainly by small growers on small areas (0.4-12 ha). These farmers have a high diversity of products per area (IPD 2010). Due to this, these small growers might represent the major agents for Cerrado biodiversity conservation if they use ecosystem services instead of conventional practices for crop management (Ferreira et al. 2012).

The objective of this study was to describe the insect communities, classified into two functional groups, herbivores and natural enemies, when a plot of agroforestry system was introduced into a vegetable production farm to enhance local plant diversity. The scientific questions that oriented our study were: (1) Do less-disturbed habitats such as agroforestry systems, favor the establishment of insect communities with higher species diversity and abundance evenness compared with horticultural crops? (2) Do agroforestry system play a role in structuring insect communities, within the functional groups of herbivores and natural enemies, in vegetable production plots? (3) Is the balance in the abundance of herbivores and natural enemies throughout the year, affected by either functional group or by stochastic factors such as meteorological conditions? We expected that by answering these questions we could understand the role of agroforestry systems in structuring insect communities, with consequences for the abundance of herbivores and natural enemies that contribute to the agro-ecosystem management and favor biological control as an ecosystem service.

\section{Materials and methods}

Study area

This study was conducted on four small farms located, at least $18 \mathrm{~km}$ distant from each other, in the Brazilian
Federal District, Brazil. These farms are characterized by the employment of mainly familiar labor in the management of crop production. When this study started growers from Farm I, II and III were interested in moving from the conventional model of vegetables production to agro-ecological model of crop production. As the first step in this "transition" process rows of agroforestry systems were introduced in each farm nearby and among vegetable planting plots to increase plant diversity in the farms. Only Farm IV (see below) had an early stage agroforestry system already established when this study started. The farmers selected the species for the agroforestry systems including native non-crop species, fruit trees, crop species based on personal experience for marketable crops and species for multiples usages, such as timber extraction, medicine and own use preference. Adaption to soil and climate conditions in the region was considered in addition (Table 1).

Farm I (11 ha) is located at the Planaltina region $\left(15^{\circ} 34^{\prime} 39^{\prime \prime} \mathrm{S} ; 47^{\circ} 44^{\prime} 27^{\prime \prime} \mathrm{W}\right)$, the grower has been planting, mainly, green corn (Zea mays L., Poaceae) (6 ha), in a conventional and irrigated monoculture system since 2005. Pest control and other agronomic practices have been performed by applying chemical products such as insecticides and synthetic fertilizers. When the grower engaged in the agro-ecological transition process, some rows of green corn were intercropped with beans. A strip of agroforestry system measuring about 0.6 ha was established at the beginning of sampling dates in this study. Farm II (8 ha) is located in the Ceilândia region $\left(15^{\circ} 49^{\prime} 25^{\prime \prime} \mathrm{S}\right.$; $\left.48^{\circ} 15^{\prime} 09^{\prime \prime} \mathrm{W}\right)$, main activity was the production of chayote (Sechium edule Swartz, Curcubitaceae) (3 ha). Other crops produced on a smaller scale, such as eggplant and some leafy vegetables, were used for subsistence. Spontaneous vegetation and medicinal plants were present within and around the planted plots. The farmer stopped using pesticides to control pests and a strip of agroforestry system measuring about 0.4 ha was established around the vegetables plots as the first step toward the agro-ecological transition process. Additionally, some fruit trees were planted in farm, as a way of enhancing the diversity of plants in the farm. Farm III (14 ha) is located in the Paranoá region $\left(47^{\circ} 38^{\prime} 13^{\prime \prime} \mathrm{W} ; 15^{\circ} 49^{\prime} 42^{\prime \prime} \mathrm{S}\right)$ and leafy vegetables was cultivated with medicinal plants and herbs (e.g. coriander and parsley) ( $0.6 \mathrm{ha}$ ) for personal consumption and subsistence. The plants were grown 
Table 1 List of main species planted in each agroforestry system on farms in December of 2008, Federal District, Brazil

\begin{tabular}{|c|c|c|c|c|c|c|c|}
\hline \multirow[t]{2}{*}{ Scientific name } & \multicolumn{3}{|l|}{ Plants } & \multicolumn{4}{|c|}{ Farms $^{\mathrm{a}}$} \\
\hline & Plant use & Architecture & Life cycle & I & II & III & IV \\
\hline \multicolumn{8}{|l|}{ Bromeliaceae } \\
\hline Ananas comosus & Food crop & Herbaceous & Semiperennial & $X$ & $X$ & $X$ & $\mathrm{X}$ \\
\hline \multicolumn{8}{|l|}{ Caricaceae } \\
\hline Carica papaya & Food crop & Herbaceous & Semiperennial & $X$ & $X$ & $X$ & $X$ \\
\hline \multicolumn{8}{|l|}{ Cucurbitaceae } \\
\hline Sechium edule & Food crop & Herbaceous & Perennial & & & & $X$ \\
\hline \multicolumn{8}{|l|}{ Dioscoreaceae } \\
\hline Dioscorea sp. & Food crop & Herbaceous & Perennial & $X$ & $X$ & $X$ & $\mathrm{X}$ \\
\hline \multicolumn{8}{|l|}{ Euphorbiaceae } \\
\hline Manihot esculenta & Food crop & Herbaceous & Annual & $X$ & $X$ & $X$ & $\mathrm{X}$ \\
\hline Ricinus communis & Oil plant & Shrub & Annual & & $\mathrm{X}$ & $\mathrm{X}$ & $\mathrm{X}$ \\
\hline \multicolumn{8}{|l|}{ Fabaceae } \\
\hline Cajanus cajan & Cover crop & Herbaceous & Annual & $\mathrm{X}$ & $X$ & $\mathrm{X}$ & $\mathrm{X}$ \\
\hline Canavalia ensiformes & Cover crop & Herbaceous & Annual & $\mathrm{X}$ & $X$ & $X$ & $\mathrm{X}$ \\
\hline Crotalaria breviflora & Cover crop & Herbaceous & Annual & $X$ & $X$ & $\mathrm{X}$ & $\mathrm{X}$ \\
\hline Crotalaria juncea & Cover crop & Herbaceous & Annual & $\mathrm{X}$ & $X$ & $X$ & $\mathrm{X}$ \\
\hline Crotalaria spectabilis & Cover crop & Herbaceous & Annual & $\mathrm{X}$ & $X$ & $X$ & $\mathrm{X}$ \\
\hline Leucaena sp. & Fodder & Tree & Perennial & $\mathrm{X}$ & $X$ & $X$ & $\mathrm{X}$ \\
\hline Mucuna pruriens & Cover crop & Herbaceous & Annual & $\mathrm{X}$ & $X$ & $X$ & $X$ \\
\hline Piptadenia sp. & Native & Tree & Perennial & & & & $\mathrm{X}$ \\
\hline \multicolumn{8}{|l|}{ Malvaceae } \\
\hline Gossypium sp. & Fiber & Herbaceous & Annual & $X$ & $X$ & & $X$ \\
\hline \multicolumn{8}{|l|}{ Meliaceae } \\
\hline Swietenia sp. & Native & Tree & Perennial & $\mathrm{X}$ & $X$ & $X$ & $\mathrm{X}$ \\
\hline \multicolumn{8}{|l|}{ Moraceae } \\
\hline Morus alba & Food crop & Tree & Perennial & $X$ & $X$ & $X$ & $X$ \\
\hline \multicolumn{8}{|l|}{ Musaceae } \\
\hline Musa speciosa & Food crop & Shrub & Perennial & $X$ & $X$ & $X$ & $X$ \\
\hline \multicolumn{8}{|l|}{ Palmaceae } \\
\hline Bactris gasipaes & Native & Tree & Perennial & $X$ & $X$ & & $X$ \\
\hline \multicolumn{8}{|l|}{ Passifloraceae } \\
\hline Passiflora edulis & Food crop & Herbaceous & Semiperennial & & $X$ & $\mathrm{X}$ & $X$ \\
\hline \multicolumn{8}{|l|}{ Poaceae } \\
\hline Saccharum sp. & Cover crop & Herbaceous & Semiperennial & & $X$ & & $\mathrm{X}$ \\
\hline Sorghum vulgare & Cover crop & Herbaceous & Annual & & $X$ & & \\
\hline Zea mays & Food crop & Herbaceous & Annual & $\mathrm{X}$ & $\mathrm{X}$ & $\mathrm{X}$ & $\mathrm{X}$ \\
\hline \multicolumn{8}{|l|}{ Punicaceae } \\
\hline Punica granatum & Medicinal & Shrub & Perennial & & & $\mathrm{X}$ & \\
\hline \multicolumn{8}{|l|}{ Rubiaceae } \\
\hline Coffea arabica/conilon & Food crop & Shrub & Semiperennial & $\mathrm{X}$ & $X$ & $\mathrm{X}$ & $\mathrm{X}$ \\
\hline Species $\left(\mathrm{N}^{\circ}\right)$ & & & & 16 & 20 & 17 & 21 \\
\hline
\end{tabular}

${ }^{a} X$ indicate plant species introduced in each the farm 
together with herbaceous plants with few cultural practices; a low exploitation rate and no use of pesticides. The main business activity of the property was hay production in most of the remaining area. A strip of agroforestry system measuring about 0.4 ha was established at the beginning of this study. Farm IV (12 ha) is located in the Taguatinga region $\left(15^{\circ} 49^{\prime} 49^{\prime \prime} \mathrm{S} ; \quad 48^{\circ} 04^{\prime} 27^{\prime \prime} \mathrm{W}\right)$, produces vegetables (5 ha) in crops rotation and intercropping organic system ( $>10$ species per plot), with organic certification since 1999. Further, there are barriers and "windbreaks", with floristic species separating the plots of vegetables. These are interspersed with agroforestry plots or orchards containing native tree species and fruit trees, associated with herbaceous, cultivated and spontaneous plants. All agroforestry systems, except the farm IV, were deployed in December of 2008.

The climate of the region is tropical semi-humid, with mean temperatures ranging from 22 to $27^{\circ} \mathrm{C}$ and an average rainfall of $1,500 \mathrm{~mm}$ per year (Klink and Machado 2005). There are two well-defined seasons throughout the year. The wet season is usually from November to March, whereas the dry season occurs from May to September. As the Cerrado biome is characterized by seasonal fluctuations of rainfall throughout the year (Klink and Machado 2005), we hypothesized that rainfall might affect species abundance together with time. Thus, rainfall data were obtained from the weather station installed in the experimental field of Embrapa Vegetables in Federal District, Brazil $\left(15^{\circ} 56^{\prime} \mathrm{S} ; 48^{\circ} 08^{\prime} \mathrm{W}\right)$.

\section{Sampling methods}

The insect fauna was sampled in the agroforestry system and the nearby horticultural crop plot at each farm simultaneously in the same day (paired design) for two group of samplers that alternate each other among the farms and months randomly. The samplings were performed from February 2009 to January 2010, always in the first week of the month. The samplers established line transects crossing the plot in different directions, and all the plants (cropped or not) on transect was entirely and carefully inspected in order to find and captures insects in its above ground structures. The plants in the agroforestry system were sampled in the same strata (about $1 \mathrm{~m}$ ) of the horticultural crop system in an attempt to standardize the collection on both systems. The insects were captured using plastic pots, insect net or insect aspirator depending on their mobility and behavior. This procedure was adopted instead of other sampling methods such as traps because this way we could measure the insect fauna present only in the sampled area and on plants. In each area the plants were inspected during $120 \mathrm{~min}$, totaling a sampling effort of $240 \mathrm{~min}$ per farm.

The insects were taken to the laboratory, where they were identified and separated into the functional groups of herbivores and natural enemies (predators and parasitoids). The identification was based on the literature and where there was a lack of published information, these were classified based on external morphology such as mouthpart morphology. Thus, an abundance of data for each selected functional group per sampling date was generated. The small insects like aphids, scale insects, mealybugs and whiteflies were not collected because they are usually in a higher scale of abundance and present an aggregate distribution in crop. These traits compromise the data analyses. Abundance of other insects such as ants and bees were not also measured because they are social insects, requiring specific sampling methods.

\section{Data analysis}

The diversity of insect communities in agroforestry systems and horticultural crop was initially compared by rarefaction curves to estimate the species richness for samples with a different number of individuals collected (Krebs 1999), and by the Rényi function to compare the diversity profile (Tóthmérész 1995). This latter function allows a continuum of possibilities of diversity measurement according to the parameter $\alpha$, where $\alpha_{0}=\log \mathrm{N}$, where $\mathrm{N}$ is the total number of a community's species; $\alpha_{1}=$ is Shannon's entropy (Shannon 1948) and $\alpha_{2}=$ Simpson's index (Simpson 1949). Further, "Rényi's entropy, differ in their sensitivity to the rare and abundant species in the community, becoming dominated by the commonest species for increasing values of the parameter $\alpha$ " (see Ricotta et al. 2002; Ricotta 2003 for details). The curves plotted from this function could be compared and allow inferences concerning the differences in diversity patterns. However, when the curves of two or more communities intersect, they cannot be compared (Tóthmérész 1995). 
Equitability ( $\mathrm{J}$ ) and dominance $(\mathrm{D}=1$-Simpson index) were used to assess how species abundance is distributed among the taxa present in samples from agroforestry systems and horticultural systems (Legendre and Legendre 2012). All diversity analyses were performed using the PAST program (Hammer et al. 2001).

The effect of crop system (agroforestry system and horticultural crops) in the abundance of each functional group was assessed using a mixed effect linear model (GLMM). In this analysis, the sampling date was used as a random variable via the maximum likelihood method (Crawley 2007). We also used a GLMM to assess whether the monthly abundance of herbivores and natural enemies was affected by each other and by the rainfall period. To accomplish this, we used a hierarchical model, where the properties and the crop system inside the properties were used as random factors. In this way, we controlled the temporal pseudo-replication in the former analysis and the spatial pseudo-replication in the latter. In both analyses, the significance of each variable was tested and non-significant factors were removed from the model and compared with the previous model until it reached a minimum adequate model (Crawley 2007). This model was compared with a null model to investigate the biological significance of the analysis. The significance of variables was tested using an Analysis of Variance (ANOVA) with a chi squared test (Crawley 2007). Previous to using the GLMM on the rainfall data, we compared the mean rainfall per period using a one-way ANOVA. All analyses were performed using the software R (R Development Core Team 2012).

\section{Results}

Diversity of functional groups communities

A total of 12,506 insects were collected and classified into ten orders, 83 families and 554 morphospecies. Among these, 6,325 individuals (ten orders, 39 families and 302 species) were identified as herbivores. In this functional group, the most abundant taxa in the horticultural and agroforestry systems were: Lagria villosa (Fabricius, 1781) (Coleoptera: Lagriidae) $(8.1 \%)$, Diabrotica speciosa (Germar, 1824) (Coleoptera: Chrysomelidae) (7.9\%), Euxesta sp.
(Diptera: Ulidiidae) (6.4\%) and Oxycarenus sp. (Hemiptera: Lygaeidae) (4.8\%). The other 6,181 individuals (eight orders, 44 families and 252 species) were classified as predators or parasitoids (natural enemies) and the most abundant species were: Condylostylus spp. (Diptera: Dolichopodidae) (43.0\%), Toxomerus lacrymosus (Bigot, 1884) (Diptera: Syrphidae) (10.8\%), Doru luteipes (Scudder, 1876) (Dermaptera: Forficulidae) (5.9\%), and Harmonia axyridis (Pallas, 1773) (Coleoptera: Coccinellidae) $(1.8 \%)$. See details in Table 2.

When comparing the community richness by rarefaction curves, there were more herbivore and natural enemy species in the agroforestry system than the horticultural system (Fig. 1). However, the diversity in these systems (compared by the Rényi profiles), showed a different pattern between functional groups (Fig. 2). The herbivores had more diverse communities in agroforestry system areas than in horticultural systems (Fig. 2a), whereas the natural enemies only differ between agroforestry and vegetable crop systems for species richness and community evenness (Fig. 2b). For natural enemies, we could not infer an overall difference related to community diversity, because the Rényi profile curves touch each other at alpha $>1$ (Fig. 2b).

Structure of functional group communities

Regarding community structure, herbivores and natural enemies had an overall abundance concentrated in a few species in both crop systems (Fig. 3). However, the individual abundance within the herbivore community was better distributed among species in the agroforestry system than the horticultural system (Fig. 3a). This pattern was not related to the species composition in such habitats; there was no shift of dominant species in each system. When comparing the ten most abundant species in the herbivore community, seven were among the most abundant in both agroforestry system and horticultural systems, and all ten occurred in both crop systems. The 20 most abundant species, from 302 species collected, comprised 59.1 and $44.9 \%$ of the individuals collected in horticultural and agroforestry systems, respectively. The similarity index between herbivore species collected in horticultural and agroforestry systems was for Sorensen $=0.78$, and for Morisita $=0.75$. 
Table 2 List of the most abundant taxa collected on areas of Horticultural Crops (Hort. Crop.) and Agroforestry Systems (Agrof. Syst.), Federal District, Brazil

\begin{tabular}{|c|c|c|c|c|c|c|}
\hline \multirow[t]{2}{*}{ Order } & \multirow[t]{2}{*}{ Family } & \multirow[t]{2}{*}{ Functional group } & \multirow[t]{2}{*}{ Species } & \multicolumn{2}{|l|}{ Abundance } & \multirow[t]{2}{*}{ Total } \\
\hline & & & & Hort. Crop. & Agrof. Syst. & \\
\hline Diptera & Dolichopodidae & Predator & Condylostylus sp. & 1,604 & 1,045 & 2,649 \\
\hline Diptera & Syrphidae & Predator & Toxomerus lacrymosus & 389 & 287 & 676 \\
\hline Coleoptera & Lagriidae & Herbivore & Lagria villosa & 325 & 185 & 510 \\
\hline Diptera & Ulidiidae & Herbivore & Euxesta sp. & 425 & 78 & 503 \\
\hline Coleoptera & Chrysomelidae & Herbivore & Diabrotica speciosa & 350 & 149 & 499 \\
\hline Dermaptera & Forficulidae & Predator & Doru luteipes & 325 & 41 & 366 \\
\hline Coleoptera & Chrysomelidae & Herbivore & Colaspis joliveti & 169 & 143 & 312 \\
\hline Diptera & Syrphidae & Predator & Ornidia obesa & 200 & 110 & 310 \\
\hline Hemiptera & Lygaeidae & Herbivore & Morphospecie 2.31 & 229 & 72 & 301 \\
\hline Hemiptera & Membracidae & Herbivore & Morphospecie 1.18 & 148 & 100 & 248 \\
\hline Coleoptera & Chrysomelidae & Herbivore & Diabrotica viridula & 151 & 63 & 214 \\
\hline Hemiptera & Miridae & Herbivore & Morphospecie 2.34 & 177 & 20 & 197 \\
\hline Orthoptera & Gryllidae & Herbivore & Morphospecie 5.3 & 97 & 60 & 157 \\
\hline Hemiptera & Cicadellidae & Herbivore & Morphospecie 1.14 & 52 & 79 & 131 \\
\hline Hemiptera & Membracidae & Herbivore & Morphospecie 1.10 & 4 & 124 & 128 \\
\hline Diptera & Tachinidae & Parasitoid & Morphospecie 0.52 & 36 & 76 & 112 \\
\hline Coleoptera & Coccinellidae & Predator & Harmonia axyridis & 107 & 3 & 110 \\
\hline Coleoptera & Curculionidae & Herbivore & Morphospecie 3.93 & 63 & 28 & 91 \\
\hline Diptera & Bombyliidae & Predator & Morphospecie 0.82 & 31 & 60 & 91 \\
\hline Hemiptera & Alydidae & Herbivore & Neomegalotomas styrex & 22 & 66 & 88 \\
\hline Hemiptera & Miridae & Herbivore & Morphospecie 2.21 & 56 & 29 & 85 \\
\hline Hemiptera & Cicadellidae & Herbivore & Morphospecie 1.32 & 72 & 12 & 84 \\
\hline Hemiptera & Coreidae & Herbivore & Morphospecie 2.42 & 43 & 37 & 80 \\
\hline Coleoptera & Elateridae & Herbivore & Morphospecie 3.32 & 55 & 24 & 79 \\
\hline Coleoptera & Coccinellidae & Predator & Cycloneda sanguinea & 52 & 23 & 75 \\
\hline Coleoptera & Coccinellidae & Predator & Scymnus sp. & 22 & 49 & 71 \\
\hline Coleoptera & Coccinellidae & Predator & Psyllobora gratiosa & 37 & 31 & 68 \\
\hline Hemiptera & Berytidae & Herbivore & Morphospecie 2.77 & 27 & 33 & 60 \\
\hline Hemiptera & Membracidae & Herbivore & Morphospecie 1.17 & 22 & 36 & 58 \\
\hline Hemiptera & Coreidae & Herbivore & Morphospecie 2.25 & 35 & 21 & 56 \\
\hline Hemiptera & Miridae & Herbivore & Morphospecie 2.19 & 21 & 34 & 55 \\
\hline Coleoptera & Chrysomelidae & Herbivore & Morphospecie 3.20 & 6 & 48 & 54 \\
\hline Coleoptera & Chrysomelidae & Herbivore & Morphospecie 3.194 & 41 & 11 & 52 \\
\hline Hymenoptera & Braconidae & Parasitoid & Morphospecie 4.64 & 46 & 5 & 51 \\
\hline Hemiptera & Coreidae & Herbivore & Leptoglossus zonatus & 41 & 9 & 50 \\
\hline
\end{tabular}

For natural enemies, the abundance distribution among species was more similar between agroforestry and horticultural systems. The values of dominance and equitability were smaller for this functional group than those obtained for the herbivore group (Fig. 3b). When comparing the ten most abundant species in the natural enemy community, five are equally the most abundant in both agroforestry and horticultural systems, and all of them occurred in both crop systems. The 20 most abundant species from the 255 species collected, comprised 83.1 and $75.4 \%$ of the individuals collected in horticultural and agroforestry 
Fig. 1 Species richness estimate by rarefaction curves of herbivore (a) and natural enemies

(b) communities in horticultural crops and agroforestry system on farms in the Federal District, Brazil, 2009/2010
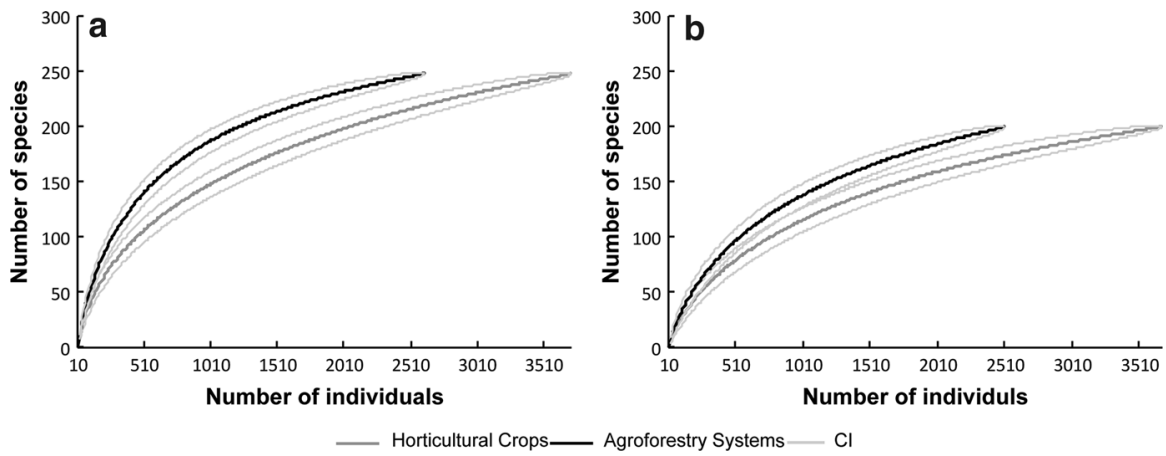

_ Horticultural Crops
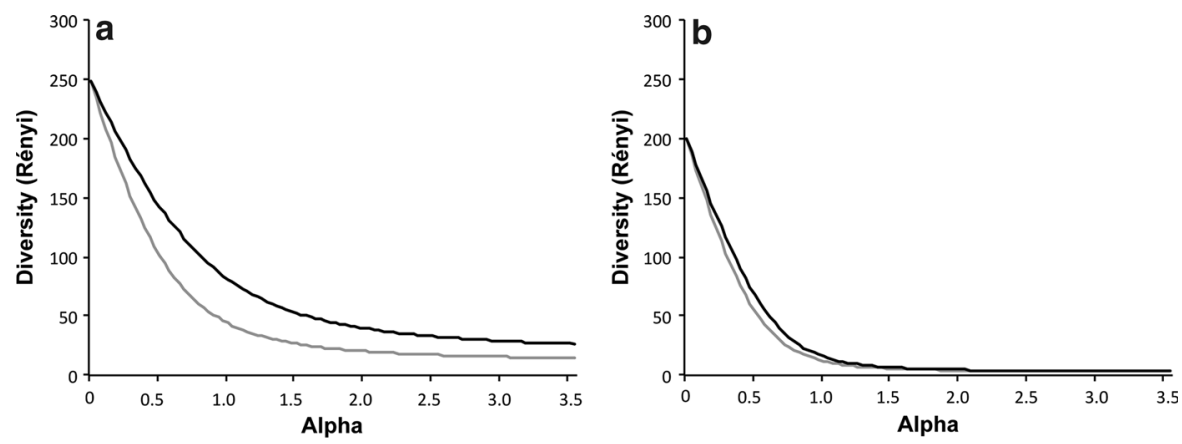

_ Horticultural Crops — Agroforestry Systems

Fig. 2 Rényi entropy describing diversity curves of herbivore (a) and natural enemies (b) communities in horticultural crops and agroforestry system on farms in the Federal District, Brazil, 2009/2010

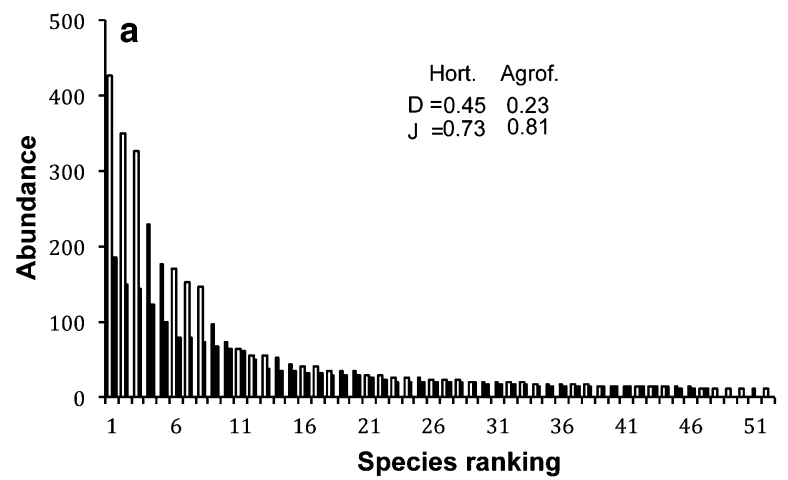

口Horticultural crops

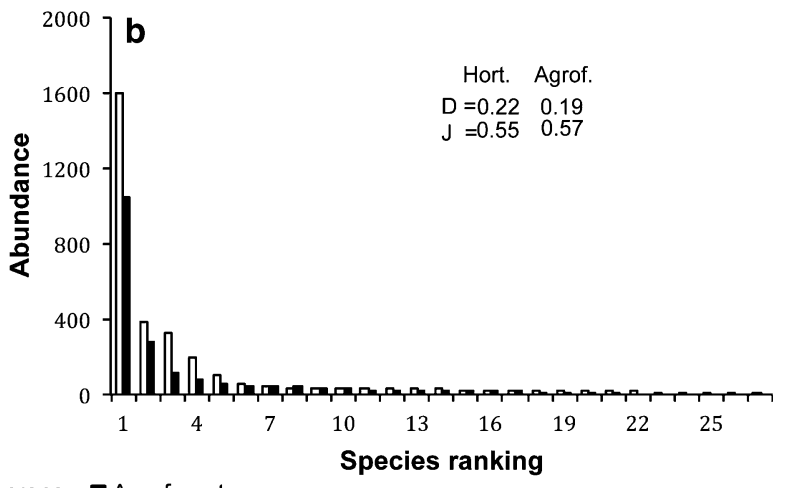

dominance and $J$ the equitability values for each functional group. Insects collected on farms in the Federal District, Brazil, 2009/2010

natural enemies $\left(F_{1,86}=7.54 ; \quad P=0.007\right)$ was affected by crop system. As the crop system appears to be one of the main factors controlling insect abundance, we compared the mean ( \pm standard deviation) abundance of both functional groups in agroforestry and horticultural systems separately. This analysis showed that natural enemies $\left(F_{1,91}=5.37\right.$; 
Fig. 4 Mean abundance of herbivores (a) and natural enemies (b) on horticultural crops and agroforestry system on farms in the Federal District, Brazil, 2009/2010. Asterisk above bars indicates significant differences between treatments by model contrast analysis $(P<0.05)$
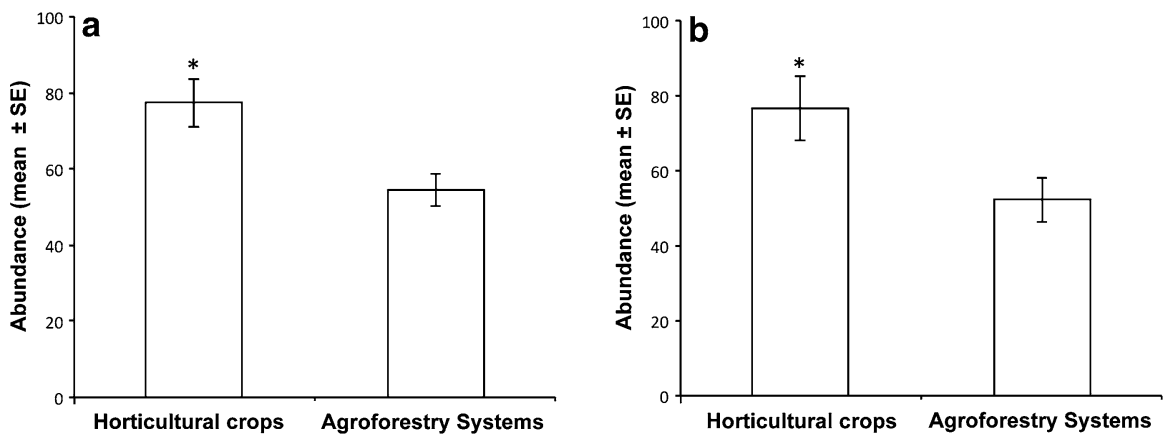

$P=0.022)$ and herbivores $\left(F_{1,91}=9.87 ; P=0.002\right)$ were more abundant in horticultural than in agroforestry systems (Fig. 4).

Biotic and abiotic factors affecting herbivores and natural enemy abundance

We initially compared the rainfall distribution along the year. There was a seasonal fluctuation in the rainfall, which produced three distinct periods that were significantly different $\left(F_{1,11}=1.85 ; P=0.003\right)$. An initial period, with a great quantity of rainfall (246.55 \pm $29.94 \mathrm{~mm}$ ) (October 2009-January 2010), a second half of the rainfall period with lower precipitation $(112.98 \pm 108.85 \mathrm{~mm})$ (February 2009-May 2009) and a dry season $(20.93 \pm 16.88 \mathrm{~mm}$ ) (June 2009September 2009) (Fig. 5).

The mixed effect model analysis showed that the abundance of natural enemies and herbivores was regulated by different factors with time. The natural enemy abundance was affected by herbivore abundance $\left(F_{1,85}=14.89 ; P<0.000\right)$ and the rainfall season $\left(F_{1,85}=7.34 ; P=0.008\right)$, but not by the interaction between these factors $\left(F_{1,85}=1.93\right.$; $P=0.168)$. Alternatively, the herbivore abundance with time was affected by the natural enemy abundance $\left(F_{1,85}=3.99 ; P=0.048\right)$ and no effects of the rainfall season $\left(F_{1,85}=0.18 ; P=0.672\right)$ or the interaction between these variables $\left(F_{1,85}=0.35\right.$; $P=0.554)$ was observed. A numerical response of natural enemies to herbivore abundance was evaluated by regression analysis, which showed that natural enemy abundance was positively related to that of herbivores, when considering the overall abundance of each functional group (Fig. 6).

\section{Discussion}

The most abundant species of each functional group were characterized as generalist insects. Such insects tend to be more mobile organisms than specialists because they can feed upon many plant species and therefore, tend to constantly move between horticultural crops (ephemeral habitats) and agroforestry systems (perennial habitats) (Jonsen and Fahrig 1997; Rand and Tscharntke 2007; Tscharntke et al. 2007). For example, the coleopteran L. villosa is a common herbivore found in the soil of different agroecosystems and is a secondary pest of strawberries and other vegetables in Brazil (Liz et al. 2009). Another coleopteran, D. speciosa, is considered an important pest of beans, soybean, corn, and potatoes (Walsh 2003). Similarly, Euxesta sp. is found mainly on maize crops, but individuals also occur on other hosts and in habitats such as weeds, orchards and natural areas (Cruz et al. 2011; Goyal et al. 2012). In terms of natural enemies, the dipterous Condylostylus sp. and T. lacrymosus, and the coccinellid $H$. axyridis are also highly mobile predators that feed on soft-body insects acting as biological control agents. The dipterous adults also feed on pollen and nectar and many coccinellids can complement their diet with these same foods from plants (Amaral et al. 2013). These resources are usually found in different patches and finding a suitable habitat for feeding and reproducing requires great mobility (Evans 2003; Evans and Toler 2007; Van Rijn and Sabelis 2005). Due to the ephemeral nature of horticultural crops and their resources, we can infer that the functional groups can colonize or become locally extinct at predictable rates in such habitats. However, agroforestry systems are more constant and perennial 
Fig. 5 Mean abundance of herbivores and natural enemies (lines) and total rainfall (bars) distribution along the year on farms in the Federal District, Brazil, $2009 / 2010$

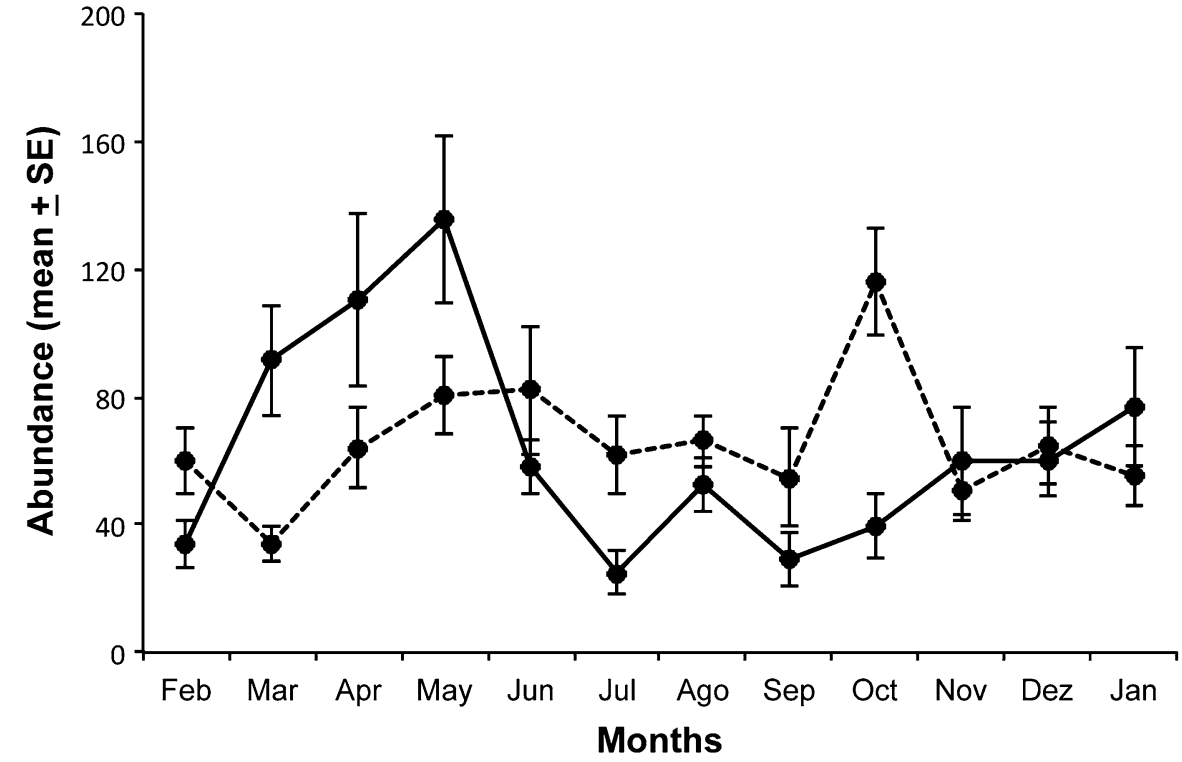

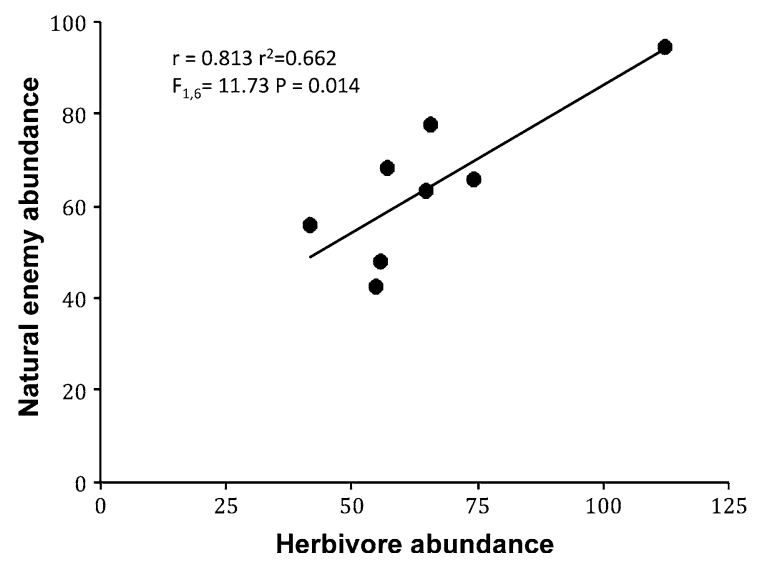

Fig. 6 Relationship between herbivore and natural enemy abundance on farms in the Federal District, Brazil, 2009/2010

habitats in the landscape. As the functional groups are dominated by organisms with high dispersal abilities, insect communities can use both habitats in the landscape in a patch-dynamics approach (Leibold et al. 2004; Pandit et al. 2009).

This mobility among habitat types in the landscape is one of the main factors that might have affected the patterns of species richness and diversity in different habitats (Mouquet and Loreau 2003; Cadotte 2006). In general, our study demonstrated that agroforestry systems can harbor more species than horticultural crops, independently of the functional group and also have a greater diversity of herbivores. Despite this, the difference in the diversity profiles of the natural enemy communities between agroforestry systems and horticultural systems is clear only at richness and evenness level of the community. Although dispersal is important, these results suggest that the factors that structure the communities of functional groups in agroforestry systems and horticultural systems are quite different.

This finding is reinforced by the fact that the community dominance, equitability and similarity between agroforestry systems and horticultural crops are higher for natural enemies than for herbivores. Nevertheless, for both functional groups, individual abundance is better distributed among species in agroforestry systems than in horticultural crops. In agroforestry systems, there is a higher plant diversity, habitat structural diversity (several plant strata with different architectures) and there are many perennial and annual plants and weeds. These traits favor the coexistence of more species that use different types of resources within different patches of the same habitat and a lower species turnover (Tscharntke et al. 2011). Agroforestry systems are also habitats with a low disturbance rate (e.g. harvesting and insecticide application), which can also contribute to their higher diversity and richness of insects. However, natural enemies, especially generalists, can find more prey in agroforestry systems, as well as shelter, oviposition 
sites and plant-provided foods such as pollen and nectar (Lundgren 2009; Amaral et al. 2013). In horticultural crops, these resources and habitat conditions are found at a lower diversity and abundance or do not exist.

Herbivores can find similar advantages in agroforestry systems regarding niche availability. In contrast, the resources used by them in the agroforestry system are mixed with others. As a general trend, agroecosystems with a higher diversity of plants have negative effects on herbivore abundance, which benefits their natural enemies (Andow 1991; Letourneau et al. 2011, 2012). In such diversified habitats, herbivores need to deal with more visual, olfactory and structural stimuli (Randlkofer et al. 2010). When exposed to mixed sensory stimuli, generalist herbivores usually have more difficulty in making choices, because their capacity to integrate information is less accurate than that of specialist herbivorous insects (neural limitation) (see Bernays 2001; Tosh et al. 2009; Togni et al. 2010b). Some herbivores also tend to remain for long periods in monocultures rather than in diversified habitats, because their hosts are more apparent and predictable as hypothesized by Root (1973). The combination of resources and conditions that are unfavorable to herbivores and favorable to natural enemies, results in agroecosystems based on the use of ecosystem services, mainly biological control (Fiedler et al. 2008).

Thereby, both functional groups were affected by the crop system (agroforestry systems or horticulture crops), with a higher abundance of insects on horticultural crops always being present than in agroforestry systems. The horticultural crops, as mentioned above, are more suitable habitats for some herbivores (Randlkofer et al. 2010; Letourneau et al. 2011), where they can achieve high reproduction rates (Altieri 1999). Horticultural crops are usually mainly colonized by species such as caterpillars, aphids, herbivorous coleopterans (i.e. D. speciosa) and whiteflies (Oliveira et al. 2001; Walsh 2003; Blackman and Eastop 2007). In some instance, our sampling methodology might have underestimated the presence of some of these insects. The high abundance that these groups can occur in some occasions may attract their natural enemies. Together, the predators Condylostylus sp., T. lacrymosus, D. luteipes and H. axyridis comprised $61.5 \%$ of the sampled natural enemies, and all of these species are known natural enemies of the non-sampled herbivore groups. These predators were found in both habitats, but were more abundant on horticultural crops where they are important predators amongst these herbivores. It is thus reasonable to assume that these natural enemies might have found more prey in the horticultural crops, which favored their colonization, establishment, reproduction and consequently their abundance. Thus, horticultural crops are habitats that favor only some species of herbivores and natural enemies, permitting their establishment in this ephemeral habitat when compared with agroforestry system. However the lack of data the non-sampled herbivores limit our inferences about this pattern and should be better investigated in further studies.

This study was conducted in the core of the Cerrado biome in Brazil. This region is characterized by alternate two well-defined seasons (rainy/dry) throughout the year that is common to all central regions of Brazil in the core of the Cerrado biome (Klink and Machado 2005). This seasonality is known to affect, for example, caterpillar abundance and their parasitism rate in natural habitats (Morais et al. 1999), as well as other insect orders (Silva et al. 2011). In this study, herbivore abundance was not affected by seasonality, but was affected only by natural enemy abundance (in agroforestry systems or horticultural crops). In a reciprocal way, the natural enemy abundance was affected by herbivore abundance as shown in Figs. 5, 6. Moreover, both functional groups were also affected by the rainfall period throughout the year. This suggests that population abundance is not only affected by biotic factors, but is also subject to stochastic process related to natural climate change, independent from prey availability. During the dry season, the climate is very dry, with air relative humidity reaching values below $15 \%$ (Oliveira-Filho and Ratter 2002) and occasionally with no rainfall (see Fig. 5). Natural enemies appear to be more sensitive to these conditions than herbivores, because this factor did not interact with herbivore abundance. For example, Togni et al. (2010a) compared the natural enemy abundance and diversity in tomato fields planted in monocultures or intercropped with coriander and irrigated by drip or sprinkler irrigation systems during the dry season within the same biome in Brazil. They found that the more diverse plots-the intercropped ones-always had more species than monocultures. However, there was a greater diversity and abundance 
of natural enemies when irrigated by sprinklers than when irrigated by the drip system. The natural enemy community structure was affected mainly by the irrigation system because the sprinklers created more favorable microclimate conditions for them (Togni et al. 2010a). Moreover, more pest outbreaks tend to occur during the dry season in this region than during other periods; there is probably a time-window during which herbivores can reproduce with a reduced pressure from their natural enemies (Morais et al. 1999; Marquis et al. 2002), even in agroecosystems.

The abundance of natural enemies was positively related to herbivore abundance, reinforcing the pressure that this functional group can create over the herbivore population. As a general trend, increasing plant diversity in the farm tends to produce a positive effect on natural enemy abundance and diversity and consequently a negative effect in herbivore populations (Letourneau et al. 2011). This pattern was previously observed in different tropical regions of the world. For example, in Kenya hedgerows crops with tree or shrub species reduced the abundance of major insect pests in maize and beans and favored the natural enemies' community (Girma et al. 2000). Rubber trees interspersed with coffee reduced leafminer damage to coffee planted in agroforestry systems in Brazil (Righi et al. 2013) and the tree richness and abundance in cocoa agroforestry systems can affect parasitoid diversity in cacao agro-forests also in Brazil (Sperber et al. 2004). Similarly, shade tree diversity reduced the herbivore damage in cocoa trees by benefiting specific guilds of natural enemies such ants, wasps and spiders in West Africa (Bisseleua et al. 2013). Mixed species plantation of native tropical timber trees presented less herbivore damage than when planted in monocultures in Panama (Plath et al. 2011). This close relationship might be related to the characteristics of agroforestry systems and horticultural crops. When some vegetables are harvested, there is a high disturbance in the area, forcing the insects to move to adjacent areas such as agroforestry system, other crops and adjacent weeds. If a particular crop is replanted, there are considerable resources available for herbivores that can colonize this area. As the herbivore population increases, they tend to be more apparent, because cues such as semiochemicals, visual cues, and others, increase due to a numerical effect (Barbosa 1998). Herbivores usually arrive into a habitat before their natural enemies (Mazzi and Dorn
2012), after this initial event, there is a greater amount of prey available for natural enemies, which then move into these habitats to search for their prey/hosts (Gurr et al. 1998). Agroforestry system can thus serve as a qualitative source habitat of mainly beneficial insects that can then colonize horticultural crop habitats (Mouquet and Loreau 2003; Cadotte 2006; Leibold et al. 2004). The abundance of beneficial insects in vegetable plots is regulated not only by the proximity of colonization sources, but also by local agricultural practices that constrain the population dynamics of these species. The landscape complexity of different habitats (e.g. agroforestry system, natural areas and horticultural crops) can affect local pest numbers in horticultural crops (Chaplin-Kramer and Kremen 2012) and explain the positive relationship found in our study.

In conclusion, establishment of agroforestry systems nearby and surrounding vegetable crop plots enhanced the diversity of herbivores and natural enemies in vegetable production farms. Integrating of agroforestry systems to vegetable crop plots served as source of natural enemies that can colonize horticultural crops when herbivores are present. However, the establishment of these beneficial insects on the farm is also related to cultural practices of crop management. As a consequence, natural enemies can establish a numerical response to herbivore abundance, but their communities are also affected by stochastic factors relating to climatic conditions. Thus, agroforestry system and agro-ecological management practices of the crop can favor an agriculture based on the maintenance and conservation of ecosystem services.

We propose the establishment of rows of agroforestry systems nearby and surrounding vegetable crop plots as hedgerows and additional source of food and products contributing for food safety of small farmers. They also act as barrier crops, windbreak and for recovering natural areas in degradation process. Plant selection for agroforestry systems should consider the farmers usage for each plant in short and long term mixing annual and perennial species, such as those introduced in the farms of the present study, mimicking the early stage of the plant succession process. However, implementing agroforestry systems do not ensure that beneficial insects will colonize the crops. To this end it is necessary that growers use less intensive management practices such as maintain strips of weeds within or surrounding crops and 
intercropping systems. Thus this will provide resources and conditions that can favor natural enemies and other beneficial insects attracting and retaining them in the crop. In regions such as the Cerrado biome in Brazil, the non favorable conditions during the dry season can be alleviated by agroforestry systems, serving as a refuge and source of natural enemies to more suitable seasons. Finally, we suggest that new efforts should be made in order to investigate the benefits involved in such agro-ecological management for other functional groups such as pollinators and decomposers and also with an interdisciplinary approach to select agricultural practices integrated to the landscape change.

Acknowledgments The authors are grateful to Milena Luçardo, Paloma VGN Milane for field assistance and insect trials; To Luciane Marinoni, Amanda C Pires, Mirian N Morales by identification of syrphids and Lúcia Massuti, Geovan $\mathrm{H}$ Côrrea, Camila F de Castro by identification of coccinellids; Raúl A Laumann and José R Pujol-Luz, for support in identification of insects. This study was supported by research grants and fellowships to the authors from the National Council of Scientific and Technological Development (CNPq) and Coordination of Higher Level Personnel (CAPES). We are also grateful to Emater and Embrapa for the financial and logistic support.

\section{References}

Altieri MA (1999) The ecological role of biodiversity in agroecosystems. Agr Ecosyst Environ 74:19-31

Altieri MA, Nicholls CI (2009) Biodiversidad y manejo de plagas en agroecosistemas. Icaria Editorial, Barcelona

Altieri MA, Letourneau DK, Davis JR (1983) Developing sustainable agroecosystems. Bioscience 33:45-49

Amaral DSSL, Venzon M, Duarte MVA, Sousa FF, Pallini A, Harwood JD (2013) Non-crop vegetation associated with chili pepper agroecosystems promote the abundance and survival of aphid predators. Biol Control 64:338-346

Andow DA (1991) Vegetational diversity and arthropod population response. Annu Rev Entomol 36:561-586

Barbosa P (1998) Agroecosystems and conservation biological control. In: Barbosa P (ed) Conservation biological control. Academic Press, San Diego, pp 39-54

Bernays EA (2001) Neural limitation in phytophagous insects: implications for diet breadth and evolution of host affiliation. Annu Rev Entomol 46:703-727

Bhagwat SA, Willis KJ, Birks HJB, Whittaker RJ (2008) Agroforestry: a refuge for tropical biodiversity? Trends Ecol Evol 23:261-267

Bisseleua HBD, Fotio D, Yede, Missoup AD, Vidal S (2013) Shade tree diversity, cocoa pest damage, yield compensating inputs and farmers' net returns in West Africa. PLoS One 8(3):e56115. doi:10.1371/journal.pone.0056115
Blackman RL, Eastop VF (2007) Taxonomic issues. In: van Emdem HF, Herrington R (eds) Aphids as crop pests. CABI International, Oxfordshire, pp 1-30

Cadotte MW (2006) Dispersal and species diversity: a metaanalysis. Am Nat 167:913-924

Chaplin-Kramer R, Kremen C (2012) Pest control experiments show benefits of complexity at landscape and local scales. Ecol Appl 22:1936-1948

Crawley MJ (2007) The R book. Wiley, Chichester

Cruz I, Silva RB, Figueiredo MLC, Penteado-Dias AM, Del Sarto MCL, Nuessly GF (2011) Survey of ear flies (Diptera: Ulidiidae) in maize (Zea mays L.) and a new record of Euxesta mazorca Steyskal in Brazil. Rev Bras Entomol 55:102-108

de Groot R, Wilson MA, Boumans MR (2002) A typology for the classification, description and valuation of ecosystem functions, goods and services. Ecol Econ 41:393-408

Evans EW (2003) Searching and reproductive behaviour of female aphidophagous ladybirds (Coleoptera: Coccinellidae): a review. Eur J Entomol 100:1-10

Evans EW, Toler TR (2007) Aggregation of polyphagous predators in response to multiple prey: ladybirds (Coleoptera: Coccinellidae) foraging in alfalfa. Popul Ecol 49:29-36

Ferreira J, Pardini R, Metzger JP, Fonseca CR, Pompeu PS, Sparovek G, Louzada J (2012) Towards environmentally sustainable agriculture in Brazil: challenges and opportunities for applied ecological research. J Appl Ecol 49:535-541

Fiedler AK, Landis DA, Wratten SD (2008) Maximizing ecosystem services from conservation biological control: the role of habitat management. Biol Control 45:254-271

Girma H, Rao MR, Sithanantham S (2000) Insect pests and beneficial arthropods population under different hedgerow intercropping systems in semiarid Kenya. Agrofor Syst 50:279-292

Gliessman SR (2007) Agro-ecology: the ecology of sustainable food systems. CRC Press, New York

Goyal G, Nuessly GS, Seal DR, Steck GJ, Capinera JL, Boote KJ (2012) Alternative plants for development of picturewinged fly pests of maize. Entomol Exp Appl 143:177-184

Gurr GM, van Emdem HF, Wratten SD (1998) In: Barbosa P (ed) Conservation biological control. Academic Press, San Diego, pp 155-183

Gurr GM, Wratten SD, Luna JM (2003) Multi-function agricultural biodiversity: pest management and other benefits. Basic Appl Ecol 4:107-116

Hammer O, Harper DAT, Ryan PD (2001) Paleontological statistics software package for education and data analyses. Paleontol Electron 4:1-9

IPD-Instituto de Promoção do Desenvolvimento (2010) Perfil do mercado orgânico brasileiro como processo de inclusão social. IPD orgânicos, Curitiba

Jonsen ID, Fahrig L (1997) Response of generalist and specialist insect herbivores to landscape spatial structure. Landsc Ecol 12:185-197

Klink CA, Machado RB (2005) The Conservation of the Brazilian Cerrado. Conserv Biol 19:707-713

Krebs CJ (1999) Ecological Methodology, 2nd edn. Addison Wesley, Menlo Park

Legendre P, Legendre L (2012) Numerical Ecology, 3rd edn. Elsevier, Amsterdam 
Leibold MA, Holyoak M, Mouquet N, Amarasekare P, Chase JM, Hoopes MF, Holt RD, Shurin JB, Law R, Tilman D, Loreau M, Gonzalez A (2004) The metacommunity concept: a framework for multi-scale community ecology. Ecol Lett 7:601-613

Letourneau DK, Armbrecht I, Rivera BS, Lerma JM, Carmona EJ, Daza MC, Escobar S, Galindo V, Gutiérrez C, López SD, Mejía JL, Rangel AMA, Rangel JH, Rivera L, Saavedra CA, Torres AM, Trujillo AR (2011) Does plant diversity benefit agroecosystems? A synthetic review. Ecol Appl 21:9-21

Letourneau DK, Allen SGB, Stireman JO III (2012) Perennial habitat fragments, parasitoid diversity and parasitism in ephemeral crops. J Appl Ecol 49:1405-1416

Lin BB, Flynn DFB, Bunker DE, Uriarte M, Naeem S (2011) The effect of agricultural diversity and crop choice on functional capacity change in grassland conversions. J Appl Ecol 48:609-618

Liz RS, Guimarães JA, Michereff-Filho M, Guedes IMR, Ribeiro MGPM (2009) Manejo do Idiamim no cultivo do morangueiro. Comunicado Técnico da Embrapa Hortaliças n. 69 , Brasília

Lundgren JG (2009) Nutritional aspects of non-prey foods in the life histories of predaceous Coccinellidae. Biol Control 51:294-305

Marquis RJ, Morais HC, Diniz IR (2002) Interactions among Cerrado plants and their herbivores: unique or typical? In: Oliveira PS, Marquis RJ (eds) The Cerrados of Brazil: Ecology and natural history of a Neotropical Savanna. Columbia University Press, New York, pp 306-328

Mazzi D, Dorn S (2012) Movement of insect pests in agricultural landscapes. Ann Appl Biol 160:97-113

Melo FPL, Arroyo-Rodriguez V, Fahrig L, Martinez-Ramos M, Tabarelli M (2013) On the hope for biodiversity-friendly tropical landscapes. Trends Ecol Evol. doi:10.1016/j.tree. 2013.01.001

Morais HC, Diniz IR, Silva DMS (1999) Caterpillar seasonality in a central Brazilian Cerrado. Rev Biol Trop 47: $1025-1033$

Mouquet N, Loreau M (2003) Community patterns in sourcesink metacommunities. Am Nat 162:544-557

Myers N, Mittermeier RA, Mittermeier CG, Fonseca GAB, Kent J (2000) Biodiversity hotspots for conservation priorities. Nature 403:853-858

Oliveira MRV, Henneberry TJ, Anderson P (2001) History, current status, and collaborative research projects for Bemisia tabaci. Crop Prot 20:709-723

Oliveira-Filho AT, Ratter JA (2002) Vegetation physiognomies and woody flora of the Cerrado Biome. In: Oliveira PS, Marquis RJ (eds) The Cerrados of Brazil: Ecology and natural history of a Neotropical Savanna. Columbia University Press, New York, pp 91-120

Pandit SN, Kolasa J, Cottenie K (2009) Contrasts between habitat generalists and specialists: an empirical extension to the basic metacommunity framework. Ecology 90: 2253-2262

Pastur GM, Andrieu E, Iverson LR, Peri PL (2012) Agroforestry landscapes and global change: landscape ecology tools for management and conservation. Agrofor Syst 85:315-318

Perrings C, Naeem S, Ahrestani F, Bunker DE, Burkill P, Canziani G, Elmqvist T, Ferrati R, Fuhrman J, Jaksic F,
Kawabata Z, Kinzig A, Mace GM, Milano F, Mooney H, Prieur-Richard AH, Tschirhart J, Weisser W (2010) Ecosystem services for 2020. Science 330:323-324

Perrings C, Naeem S, Ahrestani F, Bunker DE, Burkill P, Canziani G, Elmqvist T, Fuhrman J, Jaksic F, Kawabata Z, Kinzig A, Mace GM, Mooney H, Prieur-Richard AH, Tschirhart J, Weisser W (2011) Ecosystem services, targets, and indicators for the conservation and sustainable use of biodiversity. Front Ecol Environ 9:512-520

Plath M, Mody K, Potvin C, Dorn S (2011) Establishment of native tropical timber trees in monoculture and mixedspecies plantations: small-scale effects on tree performance and insect herbivory. For Ecol Manag 261:741-750

R Development Core Team (2012) R: A language and environment for statistical computing. R Foundation for Statistical Computing, Vienna

Rand TA, Tscharntke T (2007) Contrasting effects of natural habitat loss on generalist and specialist aphid natural enemies. Oikos 116:1353-1362

Randlkofer B, Obermaier E, Casas J, Meiners T (2010) Connectivity counts: disentangling effects of vegetation structure elements on the searching movement of a parasitoid. Ecol Entomol 35:446-455

Ratnadass A, Fernandes P, Avelino J, Habib R (2011) Plant species diversity for sustainable management of crop pests and diseases in agroecosystems: a review. Agron Sustain Dev 32:273-303

Ricotta C (2003) On parametric evenness measures. J Theor Biol 222:189-197

Ricotta C, Pacini A, Avena G (2002) Parametric scaling from species to growth-form diversity: an interesting analogy with multifractal functions. BioSystems 65:179-186

Righi CA, Campoe OC, Bernardes MS, Lunz AMP, Piedade SMS, Pereira CR (2013) Influence of rubber trees on leafminer damage to coffee plants in an agroforestry system. Agrofor Syst 87:1351-1362

Root RB (1973) Organization of a plant-arthropod association in simple and diverse habitats: the fauna of collards (Brassica oleracea). Ecol Monogr 43:92-124

Scherber C, Heimann J, Köhler G, Mitschunas N, Weisser WW (2010) Functional identity versus species richness: herbivory resistance in plant communities. Oecologia 163: 707-717

Shannon C (1948) A mathematical theory of communication. Bell Syst Tech J 27:379-423

Silva NAP, Frizzas MR, Oliveira CM (2011) Seasonality in insect abundance in the "Cerrado" of Goiás State, Brazil. Rev Bras Entomol 55:79-87

Simpson EH (1949) Measurement of diversity. Nature 163:688

Sparovek G, Berndes G, Klug ILF, Barretto AGOP (2010) Brazilian agriculture and environmental legislation: status and future challenges. Environ Sci Tech 44:60466053

Sperber CF, Nakayama K, Valverde MJ, Neves FS (2004) Tree species richness and density affect parasitoid diversity in cacao agroforestry. Basic Appl Ecol 5:241-251

Sujii ER, Venzon M, Medeiros MA, Pires CSS, Togni PHB (2010) Práticas culturais no manejo de pragas na agricultura orgânica. In: Venzon M, Júnior TJP, Pallini A (eds) Controle alternativo de pragas e doenças na agricultura orgânica. EPAMIG, Viçosa, pp 143-168 
Togni PHB, Cavalcante KR, Langer LF, Gravina CS, Medeiros MA, Pires CSS, Fontes EMG, Sujii ER (2010a) Conservação de inimigos naturais (Insecta) em tomateiro orgânico. Arq Inst Biol 77:669-676

Togni PHB, Laumann RA, Medeiros MA, Sujii ER (2010b) Odour masking of tomato volatiles by coriander volatiles in host plant selection of Bemisia tabaci biotype B. Entomol Exp Appl 136:164-173

Tosh PR, Krause J, Ruxton GD (2009) Theoretical predictions strongly support decision accuracy as a major driver of ecological specialization. P Natl Acad Sci USA 106: 5698-5702

Tóthmérész B (1995) Comparison of different methods for diversity ordering. J Veg Sci 6:283-290

Tscharntke T, Bommarco R, Clough Y, Crist TO, Kleijn D, Rand TA, Tylianakis JM, van Nouhuys S, Vidal S (2007) Conservation biological control and enemy diversity on a landscape scale. Biol Control 43:294-309

Tscharntke T, Clough Y, Bhagwat SA, Buchori D, Faust H, Hertel D, Hölscher D, Juhrbandt J, Kessler M, Perfecto I, Scherber C, Schroth G, Veldkamp E, Wanger TC (2011) Multifunctional shade-tree management in tropical agroforestry landscapes - a review. J Appl Ecol 48:619-629
Tylianakis JM, Klein AM, Tscharntke T (2005) Spatiotemporal variation in the diversity of hymenoptera across a tropical habitat gradient. Ecology 86:3296-3302

Van Rijn PCJ, Sabelis MW (2005) Impact of plant-provided food on herbivore-carnivore dynamics. In: Wäckers FL, Van Rijn PCJ, Bruin J (eds) Plant-provided food for carnivorous insects: a protective mutualism and its implications. University Press, Cambridge, pp 223-266

Vandewalle M, Bello F, Berg MP, Bolger T, Dolédec S, Dubs F, Feld CK, Harrington R, Harrison PA, Lavorel S, Silva PM, Moretti M, Santos JNP, Sattler T, Sousa JP, Sykes MT, Vanbergen AJ, Woodcock BA (2010) Functional traits as indicators of biodiversity response to land use changes across ecosystems and organisms. Biodivers Conserv 19:2921-2947

Walsh GC (2003) Host range and reproductive traits of Diabrotica speciosa (Germar) and Diabrotica viridula (f.) (Coleoptera: Chrysomelidae), two species of South American pest rootworms, with notes on other species of Diabroticina. Environ Entomol 32:276-285 